Sains Malaysiana 49(5)(2020): 1055-1066

http://dx.doi.org/10.17576/jsm-2020-4905-10

\title{
Alterations of Cholesterol Lowering-Related Proteins in the Serum of Hypercholesterolemic-Induced Rats Treated with Ficus deltoidea
}

(Pengubahan Kolesterol Protein Berkaitan Penurunan dalam Serum Tikus Teraruh Hiperkolesterolimia Dirawat dengan Ficus deltoidea)

\section{Chuo Peck Ham, Fatima Uzar, Puteri Shafinaz Abdul-Rahman, Noorlidah Abdullah \& Norhaniza AMINUDIN*}

\section{ABSTRACT}

Cardiovascular disease (CVD) is one of the major non-communicable diseases causing cardiac dysfunction and heart failure. In Malaysia, hypercholesterolemia or high blood cholesterol is known as CVD's main risk factor. Currently, there is a paradigm shift of interest in Eastern medicines as alternative prevention approaches and therapeutic cholesterol control treatment. Ficus deltoidea (Mas Cotek) is amongst the eastern medicinal plants traditionally consumed either as prevention or treatment for various diseases such as hypertension, diabetes and hypercholesterolemia. This study utilised the proteomic application in determining the changes in a series of proteins that are being differentially expressed in response to $\mathrm{F}$. deltoidea treatment of hypercholesterolemic-induced rats. Identification and quantification of proteins were conducted by using quantitative techniques, wherein two dimensional gel electrophoresis (2D-GE) along with Progenesis Samespots image analysis software and Matrix-assisted laser desorption/ionization Time-of-flight/Time-of-flight (MALDI ToF/ToF) mass spectrometry were utilised. Our results demonstrated that 14 protein spots had displayed alteration in their abundance at a minimum of 1.5 fold. Majority of these identified proteins were involved in lipid metabolism and immune system processes. These variables include apolipoprotein A1 (Apo A1), apolipoprotein E (Apo E), retinol binding protein 4 (RBP4), haptoglobin (HP), complement factor C3 (C3), complement factor C1s (C1s), transthyretin (TTR), ectonucleotide pyrophosphatase/phosphodiesterase 3 (ENPP3), prominin 1(PROM1) and plasminogen (PLG). Serum proteome analysis has unravelled the understanding on the mechanism of cholesterol reducing by F. deltoidea via augmentation of cholesterol biosynthesis that enhanced bile acids excretion, causing lowered cholesterol absorption in hypercholesterolemic rats.

Keywords: 2D-GE; differential expressions; Ficus deltoidea; hypercholesterolemia; MALDI ToF/ToF MS

ABSTRAK

Penyakit kardiovaskular (CVD) adalah sejenis penyakit tidak berjangkit paling utama yang menyebabkan disfungsi kardiak dan kegagalan fungsi jantung. Di Malaysia, hiperkolesterolemia atau kandungan kolesterol yang tinggi di dalam darah merupakan faktor risiko umum penyakit kardiovaskular. Kini, perubatan alternatif timur semakin diterima sebagai rawatan pencegahan dan terapeutik untuk mengawal paras kolesterol darah. Ficus deltoidea (Mas Cotek) adalah antara tumbuhan yang digunakan di dalam perubatan tradisi timur bagi tujuan pencegahan atau rawatan penyakit tekanan darah tinggi, kencing manis dan kolesterol darah tinggi. Kajian ini menggunakan aplikasi kaedah proteomik untuk mengenal pasti protein yang menunjukkan perubahan ketara berikutan rawatan $\mathrm{F}$. deltoidea ke atas tikus hiperkolesterolemik. Pengenalpastian dan pengkuantitian protein telah dijalankan dengan menggunakan teknik kuantitatif relatif seperti 2D-GE dengan bantuan perisian analisis imej Progenesis Samespots dan analisis spektrometer jisim MALDI ToF/ToF. Kajian kami menunjukkan terdapat 14 titik protein yang menunjukkan perubahan ketara sekurang-kurangnya 1.5 kali ganda. Kebanyakan protein yang dikenal pasti terlibat dalam metabolisma dan pengangkutan lipid serta tindak balas radang dan imun. Ini termasuklah apolipoprotein A1 (Apo A1), apolipoprotein E (Apo E), retinol binding protein 4 (RBP4), haptoglobin (HP), complement factor $C 3$ (C3), complement factor C1s (C1s), transthyretin (TTR), ectonucleotide pyrophosphatase/phosphodiesterase 3 (ENPP3), prominin 1(PROM1) dan plasminogen (PLG). Penemuan protein-protein ini memberikan maklumat baru dalam pemahaman tindak balas molekul terhadap mekanisme yang terlibat dalam penurunan kolesterol berikutan rawatan F. deltoidea melalui biosintesis kolesterol yang meningkatkan penguraian asid hempedu sekaligus menurunkan penyerapan kolesterol di dalam tikus hiperkolesterolemik.

Kata kunci: 2D-GE; Ficus deltoidea; hiperkolesterolemia; perbezaan tahap pengekspresan; spektrometer jisim MALDI ToF/ToF 


\section{INTRODUCTION}

Hypercholesterolemia (also known as dyslipidemia or high blood cholesterol) had been well known as the major risk factor contributing to worldwide cardiovascular disease (CVD) in this era (Wong 2014). The increased level of either cholesterol or low density lipoprotein (LDL) is mainly a progressive indicator of atherosclerotic lesions (Harrison et al. 2003). These lipid buildups within the coronary arteries are mostly macrophages transformed monocytes that engulf oxidised-LDL to develop foam cells or fat laden macrophages (Moore $\&$ Tabas 2011). The common risk factors for the development and aggravation of atherosclerotic include hypercholesterolemia, hypertension, smoking, and diabetes mellitus; with or without a family history, and this is related to pathophysiological vascular phenotype (Leopold \& Loscalzo 2009). However, Hansson and Libby (2006) had emphasised the substantial role of hypercholesterolemia of which it is in complementary with immune mechanisms in the pathogenesis of atherosclerosis. In order to prevent future increment of CVD, there is a need to tackle new challenges through the enormous continuous involvement of research and development efforts.

Statins or 3-hydroxy-3-methylglutaryl-coenzyme A (HMG Co-A) reductase inhibitor is a common synthetic cholesterol lowering drug used for hypercholesterolemia treatment (Ministry of Health Malaysia 2017). Besides lowering the cholesterol levels, statins inherit pleiotropic effects which include improving endothelial function, stabilising the atherosclerotic plaque, prevention of oxidative stress by reducing inflammation rate and cell damages through oxidation, and to prevent thrombosis.

Herbal medicine popularity had emerged in various countries as an alternative option to treat CVDs and other chronic diseases, such as hypertension and diabetic (Alwi et al. 2018; Tachjian et al. 2010; Thong-asa et al. 2019). F. deltoidea has been used as an alternative traditional medicine in some Asian countries (Mat et al. 2012) as it is deemed to have pharmacological properties in reducing high cholesterol level (Kalman et al. 2013). Currently, several scientific studies had shown that $F$. deltoidea potentials as antidiabetic (Misbah et al. 2013), anti-hypertensive (Razali et al. 2013), antinociceptive (Sulaiman et al. 2008), anti-inflammatory (Abdullah et al. 2009), antimelanogenic (Oh et al. 2011), and antiphotoageing (Hasham et al. 2013). This plant has also the ability to assist in uterine contraction (Ibrahim et al. 2018) as it possessed antioxidant activities (Hakiman \& Maziah 2009). It has also been reported to be a highly potential element to lessen the risk of CVD by reducing total cholesterol, LDL-cholesterol and atherogenic index (LDL/HDL ratio) as well as increasing the percentage of HDL/total cholesterol ratio (Hadijah et al. 2004).

Proteomics is the study of proteomes and its specific functions; an approach that had been widely used to analyse protein expression in blood serum, tissues, cells and body fluids (Parekh 1999). Apart from the identification of major proteins in the sample of interest; alteration in protein expression could also be detected in order to distinguish between healthy and unhealthy tissue/sample. However, there has been no extensive proteomic study carried out on serum from hypercholesterolemic rats treated with $F$. deltoidea. Thus, this current study aims to characterise the alteration in serum proteome in response to $F$. deltoidea treatment in hypercholesterolemic animals using relative quantitative proteomics techniques.

\section{MATERIALS AND METHODS}

\section{CHEMICALS AND REAGENTS}

All chemicals were obtained from Sigma Aldrich (St. Louis, MO) unless otherwise specified. Commercialised statin drug (Atorvastatin) was purchased from a registered pharmacy. IPG strips, urea, CHAPS, were obtained from GE Healthcare Bio-Sciences (Piscataway, NJ, USA). Acrylamide, bisacrylamide, TEMED, DTT, and other reagents for electrophoresis as well as silver nitrate were purchased from Merck Limited (Hercules, CA, USA). Sequencing grade trypsin was procured from Promega Corporation (Madison, WI, USA). Western Blot diaminobenzidine (DAB) substrate detection kit was obtained from Nacalai Tesque (Kyoto, Japan) whereas all antibodies (Primary antibody: chicken polyclonal antibody to haptoglobin, mouse monoclonal antibody to RBP4; secondary antibody: rabbit polyclonal antibody to chicken antibody, rabbit polyclonal antibody to mouse antibody) were purchased from Abcam Ltd. (Cambridge, UK).

\section{PREPARATION AND EXTRACTION OF Ficus deltoidea LEAVES}

The leaves of Ficus deltoidea var kunstleri were harvested from a plantation in Rembau, Negeri Sembilan, Malaysia. A voucher specimen (KLU 046470) was obtained from the Herbarium, Rimba Ilmu, University of Malaya. The leaves were air-dried before being grounded into a fine mesh. Extraction was conducted with $90 \%$ ethanol using a soxhlet apparatus (Favorit, Malaysia). The solvent was evaporated under vacuum using rotary evaporator (BUCHI Rotavapor R-114, Switzerland) and the resulting ethanolic extract (EE) was then stored in tight-capped containers at room temperature until further use.

\section{EXPERIMENTAL ANIMALS AND HYPERCHOLESTEROLEMIA INDUCTION}

Albino Wistar-Kyoto-Rats (WKY) rats weighed 120-150 $\mathrm{g}$ were purchased from the Animal House, University of Sains Malaysia (USM). All methods and procedures used in this study experiments were approved standard by the 
University of Malaya - Institutional Animal Care and Use Committee (ISB/25/04/2013/NA(R). The animals were acclimatised under standard laboratory conditions and within normal photoperiod ( $12 \mathrm{~h}$ light: $12 \mathrm{~h}$ dark cycle) for two weeks. They were being fed with commercial rat pellets and tap water, ad libitum wise. At the end of the acclimatisation period, the animals were randomly divided into five groups of six animal numbers $(n=6)$ each.

Group 1 served as the control group (C) which received normal diet and water. The other 4 groups (Group 2-5) of rats were being subjected to hypercholesterolemic state induction; the rats were fed with a high fat diet (a mixture containing roasted Bengal flour, groundnut flour, milk powder, health mix and butter) as a routine daily diet for a period of 30 days. Rats had free access to normal tap water for drinking. Wherein the cholesterol-induction state, the rats were given different doses of EE and drugs through oral gavage. Normal rats received only distilled water. Group 2 (HC) served as hypercholesterolemic control or diseased state, received distilled water; group 3 (HC-E50) received 50 $\mathrm{mg} / \mathrm{kg}$ body weight of EE; group 4 (HC-E250) received $250 \mathrm{mg} / \mathrm{kg}$ body weight of EE and group 5 (HC-Ato) received Atorvastatin $(10 \mathrm{mg} / \mathrm{kg}$ body weight) once daily for a period of 21 days. The rats were then sacrificed by $\mathrm{CO}_{2}$ asphyxiation and bloods were immediately collected through an incision made in the jugular vein. Serum samples were obtained by centrifugation at 5000 rpm for $5 \mathrm{~min}$ and stored at $-80{ }^{\circ} \mathrm{C}$ until analysis. The serum lipid profile analysis was later being outsourced to Clinical Diagnostic Laboratory (CDL), University of Malaya Medical Centre.

\section{TWO DIMENSIONAL GEL ELECTROPHORESIS (2D-GE)}

An amount of $80 \mathrm{ug}$ protein was loaded to a $24 \mathrm{~cm}$ nonlinear $\mathrm{pH}$ 4-7 immobiline linear gradient dry strip. The serum proteins were resolved accordingly to their pIs using the Ettan IPGphor3 system (GE Healthcare) with the following method set-up - Step 1 [Step and hold]: $500 \mathrm{~V}$ for $1 \mathrm{~h}$; Step 2 [Gradient]: $1000 \mathrm{~V}$ for $7 \mathrm{~h}$; Step 3 [Gradient]: $8000 \mathrm{~V}$ for $3 \mathrm{~h}$ and Step 4 [Step and hold]: $8000 \mathrm{~V}$ for $7 \mathrm{~h} 30 \mathrm{~min}$. The focused IPG strips were reduced, alkylated and subjected to SDS-PAGE using linear $11 \%$ polyacrylamide gels run on Ettan DALT Six (GE Healthcare) at $80 \mathrm{~V}$ for $1 \mathrm{~h}$ and $500 \mathrm{~V}$ for $7 \mathrm{~h}$ at $25^{\circ} \mathrm{C}$.

\section{STAINING AND IMAGING OF 2D-GE GELS}

The gels were fixed overnight prior to silver staining according to the method done by Yan et al. (2000). Subsequently, image analyses were performed using Progenesis Software (Non Linear Dynamics, Newcastle Upon Tyne, Tyne \& Wear, UK). The proteome profiles of all tested groups were then compared with the proteome of the normal group. The aligned images were grouped into their respective treatment group and evaluated statistically in the review step using ANOVA p-value.
PREPARATION OF SAMPLE FOR MASS SPECTROMETRY ANALYSIS

Silver stained spots that showed significant alteration in their abundance were excised manually, and gel plugs were later subjected to digestion procedure. Prior to digestion; the gel plugs were distained twice with $15 \mathrm{mM}$ potassium ferricyanide in a $50 \mathrm{mM}$ sodium thiosulphate, reduced using $10 \mathrm{mM}$ DTT in $100 \mathrm{mM}$ ammonium bicarbonate; and alkylated using $55 \mathrm{mM}$ iodoacetamide in $100 \mathrm{mM}$ ammonium bicarbonate. The gel plugs were dehydrated with $50 \%$ and $100 \%$ acetonitrile, respectively, and were dried in the speed vacuum. The in-gel digestion with sequencing grade trypsin (7 $\mathrm{ng}$ / $\mathrm{uL}$ ) (PROMEGA) in $40 \mathrm{mM}$ ammonium bicarbonate was carried out by overnight incubation at $37{ }^{\circ} \mathrm{C}$.

\section{PROTEIN IDENTIFICATION BY USING MALDI TOF/TOF MS ANALYSIS}

Following digestion procedures, proteins were extracted from the digested gel plugs using acetonitrile. Dried extracted protein samples were then prepared to cleanup step using C18 Ziptip ${ }^{\mathrm{TM}}$ (Millipore, Bedford, MA). An equivalent volume of eluted samples and matrix $(6 \mathrm{mg} /$ $\mathrm{mL} \alpha$ - cyano-4-hydroxy-transcinnamic acid) were mixed and transferred onto MALDI ToF/ToF sample plate (384 Opti-TOF $123 \times 81 \mathrm{~mm}$, ABSciex). The samples were allowed to air dry and then analysed using $\mathrm{ABI}$ 4800 MALDI ToF/ToF Plus (Applied Biosystems, Foster City, USA) mass spectrometer. The MS along with MS/ MS spectra were matched with the theoretical peptide masses using the Mascot ${ }^{\mathrm{TM}}$ database search engine v2.2.03 (Matrix Science Ltd., London, UK) and searched against SwissProt 51.6 database with the following setups: Trypsin cleavage; allowed one missed cleavage; fixed modification: carboxymethylation of cysteine (C); variable modification: oxidation of methionin (M); MS precursor mass tolerance was set to $\pm 100 \mathrm{ppm}$, mass tolerance set at $\pm 0.2 \mathrm{Da}$. and monoisotopic with $\mathrm{MH}+$ mass value. The unmatched peptides were analysed using Profound software accessible online: http://prowl. rockefeller.edu/prowl-cgi/profound.exe with Rattus as taxonomy category; mass range of 0 to $100 \mathrm{kD} a$; protein pI in between 4 and 7; allowed one missed cleavage and $\mathrm{MH}^{+}$charge state with mass tolerance of 0.5 to $1.15 \mathrm{Da}$.

\section{NETWORK ANALYSIS}

Functional analysis of the differential expressed proteins were carried out using Ingenuity Pathway Analysis (IPA) software (Ingenuity Systems, http://www.ingenuity. $\mathrm{com} /$ ) to generate a predicted network based on different biofunctions. At least 10 identified protein details and quantitative fold expressed were imported into IPA software for pathway and functional analysis. The networks were scored accordingly by IPA based to the significance of the proteins (calculated p-value) in the network using right tailed Fisher's exact test. 


\section{VALIDATION OF DIFFERENTIALLY ALTERED PROTEINS BY WESTERN IMMUNOBLOT ANALYSIS}

Serum samples were reduced by 2-mercaptoethanol prior to loading onto the wells of $4 \%$ stacking gel and $12.5 \%$ SDS-PAGE. Electrophoresis was conducted at 60 $\mathrm{mA}$ and later increased to $120 \mathrm{~mA}$ once it reached the separating gel phase. Proteins were transferred onto nitrocellulose membranes under semi-dry conditions by using Trans-Blot ${ }^{\circledR}$ SD Semi-Dry electrophoretic transfer cell (Biorad, USA). The membranes were first blocked with $5 \%$ non- fat milk in TBS/0.1\% Tween-20 (TBST) overnight at $4{ }^{\circ} \mathrm{C}$ (HP) and $1 \mathrm{~h}$ at room temperature (RBP4). The membranes were consequently washed twice with fresh TBST for 5 and $10 \mathrm{~min}$, respectively. Antibody solutions were prepared using 5\% nonfat milk in TBST: For detection of HP, the antibody binding procedure involved overnight incubation at 4 ${ }^{\circ} \mathrm{C}$ with the primary chicken anti-haptoglobin antibody (1:1000 dilution, Abcam, Cambridge, UK), followed by horseradish peroxidase (HRP)-conjugated secondary antibody (1:10000 dilution rabbit anti-chicken, Abcam, Cambridge, UK) incubation for two hours at room temperature. For detection of RBP4, membrane was probed for one hour at room temperature with primary rabbit anti-RBP4 antibody (1:200 dilution, Abcam, Cambridge, UK) and then incubated at room temperature for two hours with secondary antibody (1:1000 dilution rabbit anti mouse, Abcam, Cambridge, UK). Bands on the membrane were developed with a substrate, 3,3'-diaminobenzidine (DAB Nacalai Tesque, Kyoto, Japan) consolidated with the metal enhancer for DAB stain in the presence of hydrogen peroxide. The intensity of both HP and RBP4 bands were visually compared against the loaded protein ladder with molecular weight markers range from 11 to $245 \mathrm{kDa}$.

\section{RESULTS}

\section{SERUM LIPID PROFILE ANALYSIS}

Rats serum lipid profiling (Table 1) showed an obvious difference in the profile between healthy and diseasestate groups. Hypercholesterolemic-induced group (HC) demonstrated an increase in all the observed parameters; triglycerides and total cholesterol levels were significantly increased by $61.5 \%$ and $52 \%$, respectively, while HDL was increased by $25.2 \%$ compared to the control. The increment in LDL was also seen as it appeared to reach the detectable value as oppose to the controlled rate. Treatment with atorvastatin demonstrated normalising effects whereby all observed parameters were lowered compared to HC. A similarly reduced trend was also observed following the administration of Ficus sample, HC-E50 and HC-E250 compared to HC with an exception to the increase in HDL level in the HC-E250 treated sample. Treatment with HC-E50 appeared to exhibit a better normalising effect compared to HC-E250.

TABLE 1. Serum lipid profile of hypercholesterolemic-induced rats

\begin{tabular}{|c|c|c|c|c|}
\hline \multirow{2}{*}{ Group } & \multicolumn{3}{|c|}{ Lipid parameters $\left(10^{-2} \mu \mathrm{mol} / \mathrm{l}\right)$} & \multirow[b]{2}{*}{ LDL } \\
\hline & TG & $\mathrm{TC}$ & HDL & \\
\hline $\mathrm{C}$ & $0.59 \pm 0.08$ & $3.78 \pm 0.13$ & $3.49 \pm 0.16$ & ND \\
\hline $\mathrm{HC}$ & $0.95 \pm 0.21^{*}$ & $5.74 \pm 0.48^{*}$ & $4.37 \pm 0.13$ & $0.16 \pm 0.10$ \\
\hline HC-E50 & $0.57 \pm 0.14^{* *}$ & $4.53 \pm 0.33$ & $3.93 \pm 0.23$ & $0.05 \pm 0.05$ \\
\hline HC-E250 & $0.70 \pm 0.16$ & $5.28 \pm 0.18$ & $4.55 \pm 0.14$ & $0.13 \pm 0.08$ \\
\hline HC-Ato & $0.57 \pm 0.07$ & $4.40 \pm 0.39$ & $4.03 \pm 0.32$ & ND \\
\hline
\end{tabular}

Values are mean \pm SD. * indicates statistical significance against $\mathrm{C}(\mathrm{p}<0.05) . * *$ indicates statistical significance against $\mathrm{HC}(\mathrm{p}<0.05)$

TG: Triglycerides, TC: Total cholesterol, HDL: High density lipoproteins, LDL: Low density lipoproteins, ND: Not detected, below threshold level, C: Control/normal rats, HC: hypercholesterolemic-induced rats, HC-E50: hypercholesterolemic-induced with Ficus-treated rats $(50 \mathrm{mg} / \mathrm{kg}$ EE), HC-E250: hypercholesterolemic-induced with Ficus-treated rats ( $250 \mathrm{mg} / \mathrm{kg}$ EE), HC-Ato: hypercholesterolemicinduced with atorvastatin-treated rats, Units are in micromol per liter $(\mu \mathrm{mol} / \mathrm{l})$ 


\section{D-GE PROTEOMICS ANALYSIS}

2D-GE analysis of serum proteomes from treated and nontreated hypercholesterolemic- induced rats were performed. Nearly 1000 individual spots ranging from 7 to $210 \mathrm{kDa}$ with pI between 4 and 7 were discovered using Progenesis Samespots software. We observed 27 protein spots that were significantly different with $\mathrm{p}$ values less than 0.05 (ANOVA) when compared with those in controlled (normal) groups. Based on MALDI ToF/ToF MS data search, ten spots were matched with known proteins in MASCOT database and four other protein spots with low MOWSE score from this search were re-analysed using the Profound software, using data of the non-matched peptides. A significant Z-score (Est'd Z) of 2.43 with a high probability of $1.0 \mathrm{e}+000$ denotes $99.5 \%$ confidence level with only $0.5 \%$ false positive. The identified proteins were presented in the 2D-GE maps of master gel visualised by silver staining (Figure 1). The names of the identified proteins and their respective abbreviations are listed in Table 2.

These significantly altered proteins were mainly associated with lipid metabolism and transport, inflammation and immune response, anti-oxidant protein, acute phase protein, cholesterol homeostasis and cholesterol binding. Other identified proteins were involved in pheromone binding and coagulation. Based on the past literature research, the categorised functions of these proteins are depicted in Figure 2.

Comparative analysis of spot abundancy pattern of each identified protein is shown in Figure 3. HC or diseased state rats demonstrated an increased in abundance of C3, ENPP3, C1s, CPI, RBP4, PROM1, Apo E, HP, PLG and decreased in abundance for TTR, MUP and Apo A1. Atorvastatin (Ato), the common cholesterol lowering drug demonstrated distinguished increase of Apo A1, TTR, CPI and HP but decreased abundance of Apo E, PROM1, RBP4, PLG, MUP, C1s and C3 when compared to $\mathrm{HC}$. With comparison to $\mathrm{HC}$, treatment with higher dosage of $F$. deltoidea extract $(250 \mathrm{mg} / \mathrm{kg}$, HCE250) markedly induced increment of Apo A1, CPI and HP; and decrease of ENPP3, C3, TTR, Apo E, C1s, PROM1, MUP, PLG and near normalisation of RBP4. However, treatment with low dosage of $F$. deltoidea extract (50 $\mathrm{mg} / \mathrm{kg}$, HC-E50), nearly normalised the TTR level in hypercholesterolemic-induced rats. Other proteins like CPI, PROM1, RBP4 and PLG demonstrated similar pattern as observed in HC-E250. However, HP and C3 exhibited spots with greater intensities when compared to HC-E250.

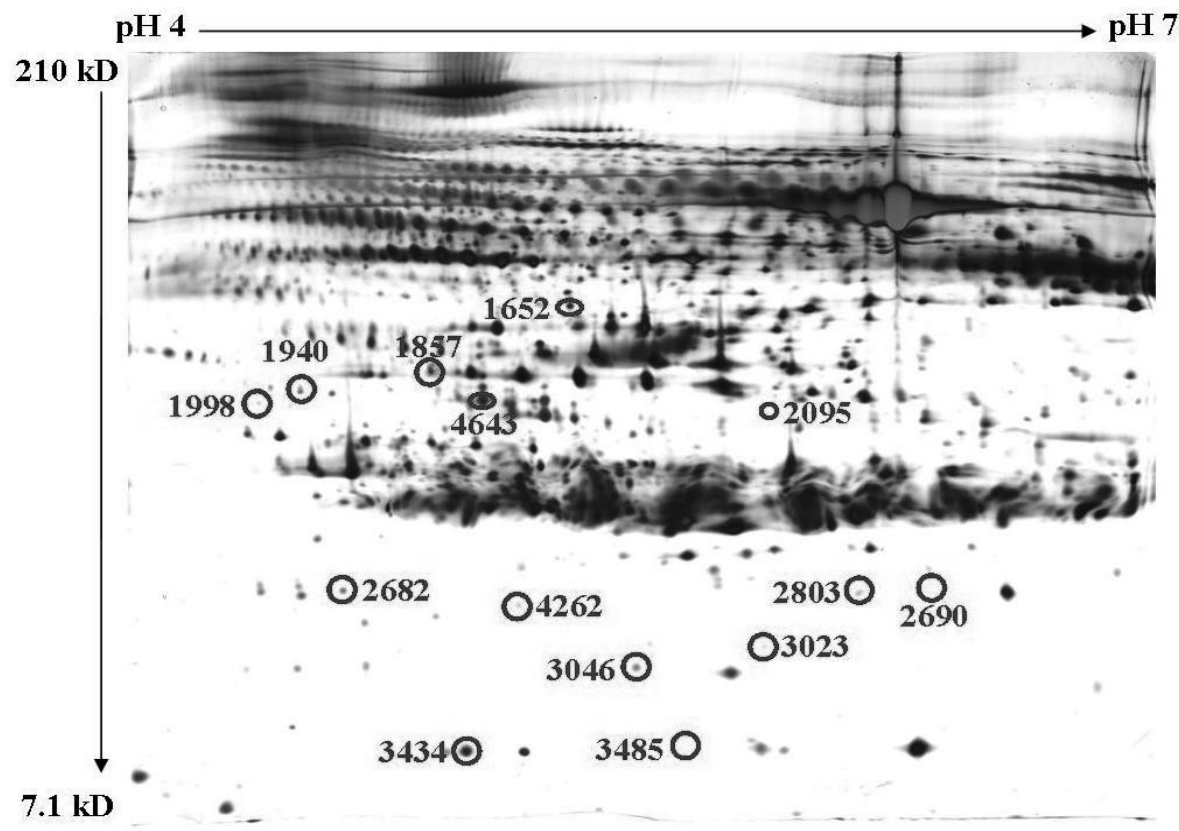

FIGURE 1. A representative 2D-GE gel of serum proteins from hypercholesteromic-induced rats.2D-GE was performed using 80 ug of protein sample loaded onto an IPG strip (pH range 4-7) and subsequently separated on $11 \%$ SDS-PAGE 
TABLE 2. List of significantly altered proteins identified by MALDI ToF/ToF

\begin{tabular}{|c|c|c|c|c|c|c|c|c|c|c|}
\hline \multirow[b]{2}{*}{ Spot ID } & \multirow[b]{2}{*}{ Protein Identification } & \multirow{2}{*}{$\begin{array}{c}\text { Acc } \\
\text { number/ } \\
\text { SWISS } \\
\text { PROT }\end{array}$} & \multicolumn{2}{|c|}{ MASCOT $^{\mathrm{a}}$} & \multirow{2}{*}{$\begin{array}{l}\text { Profound } \\
\text { (Est'd Z } \\
\text { score) }\end{array}$} & \multirow{2}{*}{$\begin{array}{c}\text { Sequence } \\
\text { coverage } \\
(\%)\end{array}$} & \multicolumn{2}{|c|}{ Theoretical } & \multicolumn{2}{|c|}{ Observed } \\
\hline & & & $\begin{array}{l}\text { Mascot } \\
\text { score }\end{array}$ & $\begin{array}{c}\text { Matched } \\
\text { peptide }\end{array}$ & & & $\begin{array}{r}\mathrm{Mw} \\
(\mathrm{kDa})\end{array}$ & $\mathrm{pI}$ & $\begin{array}{r}\mathrm{Mw} \\
(\mathrm{kDa})\end{array}$ & $\mathrm{pI}$ \\
\hline \multicolumn{11}{|c|}{ A. Mascot Database search : http://www.matrixscience.com } \\
\hline 1652 & Complement $\mathrm{C} 3$ precursor $(\mathrm{C} 3)$ & P01026 & 60 & $21 / 85$ & & 24.7 & 186.5 & 6.1 & 35 & 5.4 \\
\hline 1998 & $\begin{array}{l}\text { Contrapsin-like protease inhibitor } 1 \\
\text { precursor }(\mathrm{CPI})\end{array}$ & P05545 & 75 & $2 / 18$ & & 11.1 & 44.6 & 5.3 & 46.8 & 5.3 \\
\hline 2690 & Apolipoprotein A1(Apo A1) & P04639 & 25 & $5 / 40$ & & 12.5 & 27.4 & 5.5 & 13 & 6.5 \\
\hline 2803 & $\begin{array}{l}\text { Retinol binding protein } 4 \text { precursor } \\
\text { (RBP4) }\end{array}$ & P04916 & 242 & $10 / 72$ & & 13.8 & 21.4 & 6 & 14 & 6.2 \\
\hline 3046 & Major urinary protein (MUP) & P02761 & 71 & $7 / 104$ & & 6.7 & 17.6 & 5.4 & 11 & 5.5 \\
\hline 3434 & Haptoglobin (HP) & P06866 & 108 & $2 / 2$ & & 100 & 36.6 & 6 & 8 & 4.9 \\
\hline 3485 & Transthyretin (TTR) & Р02767 & 30 & $6 / 70$ & & 8.6 & 13.6 & 5.8 & 7.1 & 5.6 \\
\hline 4262 & Plasminogen (PLG) & Q01177 & 29 & $2 / 16$ & & 12.5 & 88.3 & 6.8 & 14 & 5.1 \\
\hline 4643 & Apolipoprotein E (Apo E) & Q6PAH0 & 259 & $19 / 35$ & & 54.0 & 33.8 & 5.2 & 29 & 5.0 \\
\hline 2095 & Complement $\mathrm{C} 1 \mathrm{~s}(\mathrm{C} 1 \mathrm{~s})$ & Q6P6T1 & 45 & $3 / 24$ & & 7.1 & 75.3 & 4.7 & 28 & 5.9 \\
\hline
\end{tabular}

B. Profound Database search : http://prowl.rockefeller.edu/prowl-cgi/profound.exe

\begin{tabular}{|c|c|c|c|c|c|c|c|c|}
\hline 1857 & $\begin{array}{l}\text { Prominin-1 isoform } 2 \text { precursor } \\
\text { (PROM1) }\end{array}$ & Q7TSL4 & 2.43 & 14.0 & 93.2 & 6.1 & 31 & 4.9 \\
\hline 3023 & $\begin{array}{l}\text { Ectonucleotide pyrophosphatase/ } \\
\text { phosphodiesterase } 3 \\
\text { (ENPP3) }\end{array}$ & P97675 & 2.43 & 14.0 & 99.2 & 5.9 & 90 & 5.9 \\
\hline 2682 & $\begin{array}{l}\text { Islet cell autoantigen 1-like protein } \\
\text { (Ica11) }\end{array}$ & Q6RUG5 & 2.43 & 35.0 & 48.6 & 5.2 & 15 & 4.6 \\
\hline 1940 & $\begin{array}{l}\text { Ectoderm-neural cortex protein } 2 \\
(\mathrm{ENC} 2)\end{array}$ & Q4KLM4 & 2.07 & 22.0 & 65.8 & 6.3 & 31 & 4.5 \\
\hline
\end{tabular}

\footnotetext{
${ }^{a}$ denotes Mascot probability based molecular weight search score calculated for PMF. Protein score is $-10 \times \log [\mathrm{P}]$, where $\mathrm{P}$ is the probability that the observed match is a random event. The scores are based to Swiss-Prot database using the MASCOT searching program in MS/MS spectra

*Z-Score estimation corresponds with the percentile of the search with significant certainty: $Z$ score $1.282=90 \% ; 1.645=95 \% ; 2.326=99 \%$; $3.09=99.9 \%$ confidence
} 
A

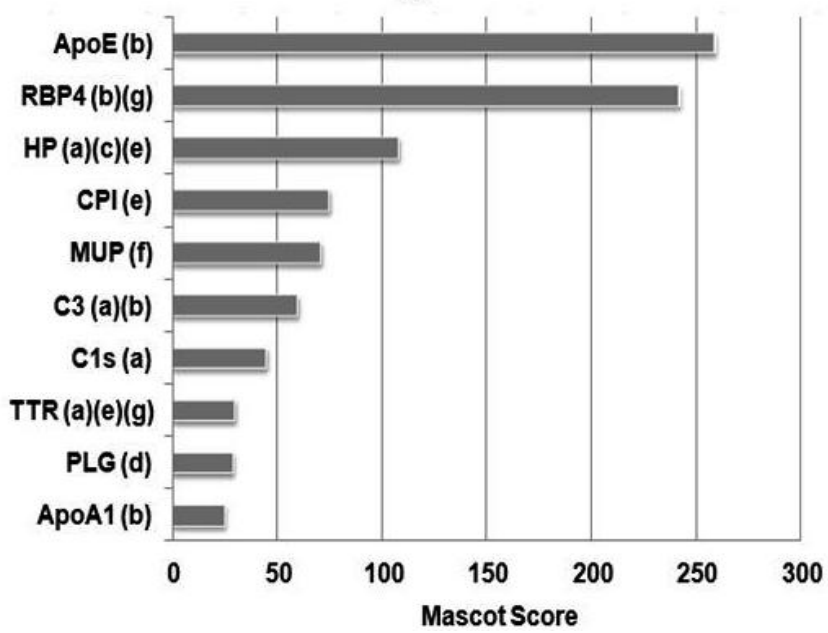

B

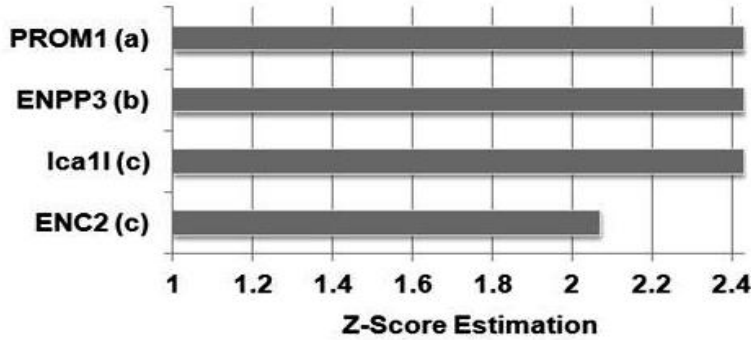

FIGURE 2. Categorised functions of identified proteins acquired by data search

A - data search using MASCOT database. The identified proteins were displayed horizontally with respective categorised functions.(a) Inflammation and immune response; (b) Lipid metabolism and transport; (c) Anti-oxidant protein; (d) Coagulation/fibrinolysis; (e) Acute phase protein; (f) Pheromone binding; (g) Cholesterol homeostasis

B - data search using Profound. Identified proteins were displayed horizontally with categorised functions (a) Cholesterol binding; (b) Inflammation and immune response; (c) unknown

\begin{tabular}{|c|c|c|c|c|c|}
\hline \multirow{3}{*}{$\begin{array}{l}\text { Spot number / } \\
\text { Identified } \\
\text { Protein }\end{array}$} & \multicolumn{5}{|c|}{ Protein Expression } \\
\hline & \multirow{2}{*}{ Control } & \multicolumn{4}{|c|}{ Hypercholesterolemic-diet induced } \\
\hline & & IIC & HC-Ato & HC-E250 & HC-E50 \\
\hline $\begin{array}{l}1998 \\
\text { CPI }\end{array}$ & & & & -2 & \\
\hline $\begin{array}{l}1857 \\
\text { PROM1 }\end{array}$ & & & & & \\
\hline $\begin{array}{c}3023 \\
\text { ENPP3 }\end{array}$ & & & & & \\
\hline $\begin{array}{l}3046 \\
\text { MUP }\end{array}$ & & & & & \\
\hline $\begin{array}{c}1652 \\
\text { C3 }\end{array}$ & & & & & \\
\hline 2803 & & & & & \\
\hline 2095 & & & & & \\
\hline $\begin{array}{l}3485 \\
\text { TTR }\end{array}$ & & & & & \\
\hline $\begin{array}{c}3434 \\
\text { HP }\end{array}$ & & & & & \\
\hline $\begin{array}{c}2690 \\
\text { Apo A1 }\end{array}$ & & & & & \\
\hline $\begin{array}{c}4643 \\
\text { Apo E }\end{array}$ & & & & & \\
\hline 4262 & & & & & \\
\hline & & & & & \\
\hline
\end{tabular}

FIGURE 3. Protein spots differential abundancy patterns for treated and non-treated hypercholesterolemicinduced rats. Magnified spots of 2D-GE images represent differential abundancy patterns between the different rat groups 


\section{NETWORK ANALYSIS}

The biological functions of the proteins identified were further investigated using Ingenuity Pathway Analysis (IPA) software. The altered proteins subjected to IPA analysis generated network with highest score of 25 on 'Lipid Metabolism, Molecular Transport, Small Molecule Biochemistry' with acute phase response signaling being ranked the highest significance of $p<$ $8.28 \times 10^{13} \mathrm{in}$ a canonical pathway analysis as tabulated in Table 3. Figure 4 shows an interactive IPA predicted network analysis between Apo A1, Apo E, RBP4, HP, ENPP3, C3, C1s, PROM1, TTR and PLG. However, the other two putative proteins, CPI and MUP were not linked in the network analysis.

TABLE 3. Top network and canonical pathway generated by Ingenuity Pathway Analysis (IPA) software

\begin{tabular}{lc}
\hline \multicolumn{1}{c}{ Associated network functions } & Score $^{a}$ \\
\hline Lipid Metabolism, Molecular Transport, Small Molecule Biochemistry & 25 \\
Cardiovascular System Development and Function, Cellular Development, & 3 \\
Cellular Function and Maintenance & Pop canonical pathway \\
\hline Acute Phase Response Signaling & $8.28 \mathrm{E}-13$ \\
Atherosclerosis Signaling & $3.48 \mathrm{E}-05$
\end{tabular}

\footnotetext{
${ }^{\mathrm{a}}$ A score of 2 or higher indicate at least $99 \%$ confidence of not being generated by random chance and higher scores indicate a greater confidence
}

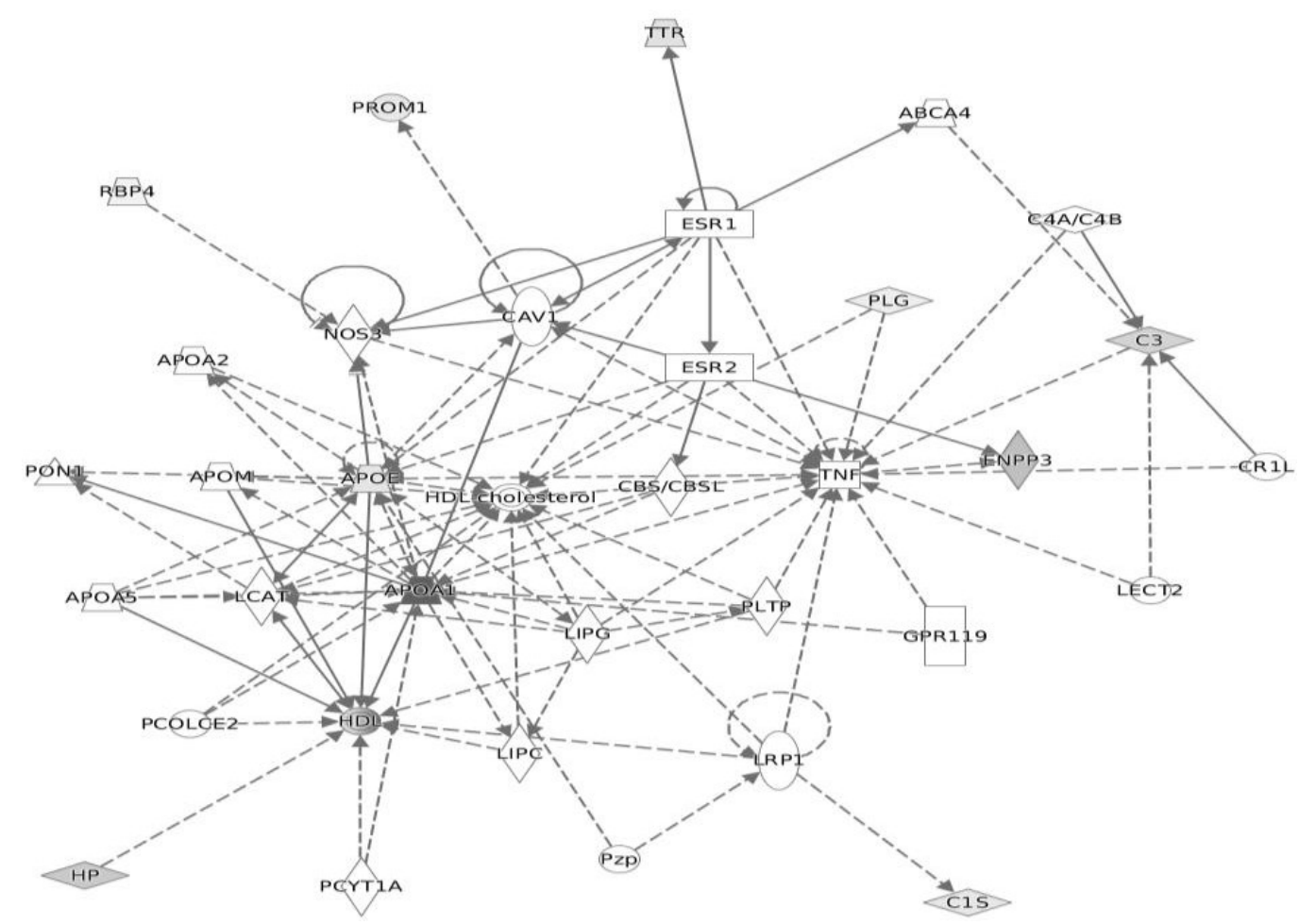

FIGURE 4. IPA generated network based on the up and down regulated proteins in response to the hypercholesterolemic and $F$. deltoidea treatments. This was the top scoring network with the displayed nodes (proteins) associated directly (solid lines) or indirectly (dashed lines) 


\section{VALIDATION BY WESTERN IMMUNOBLOTTING}

Consecutively to validate the differentially expressed proteins detected by the proteomics analysis, Western blotting of $\mathrm{HP}(\mathrm{MW} \approx 11 \mathrm{kDa})$ and RBP4 $(\mathrm{MW} \approx 20 \mathrm{kDa})$ were performed. The protein quantification of HP and RBP4 were randomly selected respectively from two different functional groups for Western blot validation. Other proteins were not validated due to scarcity of the serum samples. Pooled normal serums (Lane A) were used as the control sample. Protein expression levels of both HP and RBP4 were increased abundantly in hypercholesterolemic-induced rats. Following Atorvastatin and $F$. deltoidea extract treatments, HP was further increased, however in contrary, RBP4 was decreased. As shown in Figure 5, the alterations of these differentially expressed proteins were in agreement with 2D-GE results, which implicated the coherency of 2DGE result. As reported by Graham et al. (2007), Western blot is the 'gold standard' assessment for RBP4.

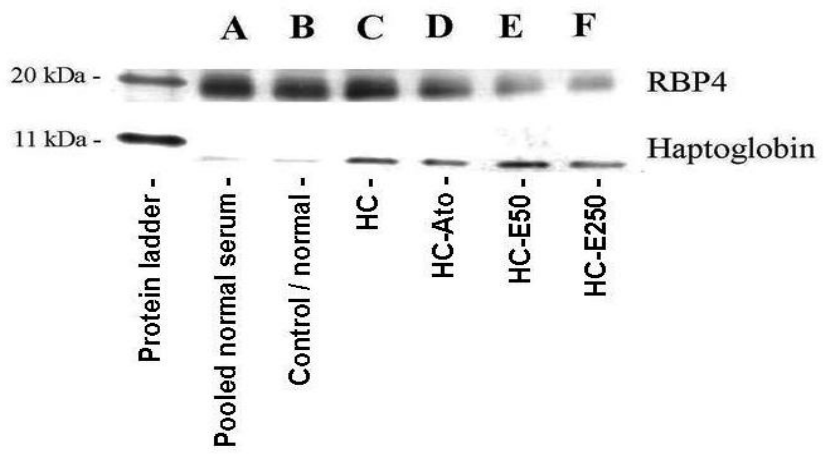

FIGURE 5. Western immunoblot validation for serum levels of HP and RBP4 in hypercholesterolemic-induced rats

\section{DISCUSSION}

The cholesterol-lowering effect of $F$. deltoidea on lipid profile and proteomic analysis in hypercholesterolemicinduced rats was evaluated in this study. The outcome of lipid profiling included cholesterol (TC), triglyceride (TG), high density lipoprotein (HDL) and low density lipoprotein (LDL) serum levels showed that $F$. deltoidea extract at lower concentration concomitant with cholesterol lowering drug (Atorvastatin) in decreasing TC, TG, and LDL levels when compared to the HC group. Both HC-E50 and HC-Ato treated group demonstrated a normalising effect as the reduced levels of TC, TG and LDL were almost nearing the baseline values of control rats. Alongside the marked reduction in both TC and TG levels, these treatments showed elevated HDL cholesterol level (compared to control value) indicating the beneficial effects of medicinal plant extract administration in preventing or reducing the risk of CVD. These observations suggested that $F$. deltoidea extract may influence suppression of cholesterol synthesis, thus exaggerate receptor-mediated catabolism of LDLcholesterol and increased fecal bile acid secretion in rats (Khanna et al. 1996). Contrary in HC-E250 treated group, TC, TG and LDL levels were not significantly reduced when compared to the HC group. It was discovered that lipid levels were not notably improved regardless higher dosage of anti-cardiovascular drugs used (Laufs et al.
2016). This concomitantly to avoid the plausible side effect associated with higher doses treatment.

This present study discovered 14 significant protein spots that showed differential expressions of $>1.5$ fold. Among the identified differential proteins, we are immensely interested in ten proteins (Apo A1, Apo E, RBP4, HP, ENPP3, C3, C1s, PROM1, TTR, and PLG), which are associated with inflammation and immune response, lipid transport and metabolism, cholesterol homeostasis, and cholesterol binding. HDL, and LDL are major cholesterol carriers in blood plasma. Both lipoproteins levels are usually contrary, where a low level of HDL and elevated LDL contributes to coronary artery disorder (CAD). High level of HDL however, integrally demonstrated cardioprotective effect (Heinecke 2009). Apo A1 and Apo E are main protein components of HDL and LDL, respectively. These apolipoproteins also play important roles in cholesterol transport and metabolism. In line with this, a decrease in abundance was observed for Apo A1 in $\mathrm{HC}$ serum proteome in comparison to control rats whereas Apo E was elevated. Treatment with F. deltoidea extract caused an increase in Apo A1 and reduced Apo E abundancies. These observations reflect the lipid profile pattern following HC-E50 and HC-E250 treatments. Abundance changes in Apo A1 and Apo E following treatment with atorvastatin showed an almost similar manner as HC-E50, which also in agreement with 
the lipid profile analysis. This study suggests that the use of atorvastatin and $F$. deltoidea may lead to the elevation of serum HDL that consequently will inhibit cholesterol build-up and clearance of cholesterol-rich proteins from plasma, respectively.

It has been showed that RBP4, the fat mimicking adipokines in transporting retinol (Vitamin A) is a potential metabolic and cardiovascular biomarker associated with hypercholesterolemia (Carbone et al. 2015). Our study had experimentally demonstrated an increase of RBP4 level in HC rats. This hypercholesterolemia event may lead to adipocyte cholesterol overload and thus inflammation. Among the metabolic syndromes, hypercholesterolemia with non-metabolic disorder like obesity or diabetes elucidated the greater affiliation with RBP4 (Kim et al. 2011). Post F. deltoidea treatments experimentally exhibit normalised RBP4 expression. The proteomic outcomes of 2D-GE and Western blotting clearly showed corresponding results prior and after $F$. deltoidea treatment, indicating the treatment possess cholesterol lowering activity along with remarkable impact towards high fat-diet given.

HP is an acute phase protein that helps to bind hemoglobin and lower the risk of iron loss, thus, acting as an antioxidant. In the previous study, Carbone and Montecucco (2015) reported several fold increase of plasma HP with systemic inflammatory stimuli on infection, malignancy and cardiovascular events. In our study, HP in HC group was increased in abundance compared to the controlled value. This increment could be suggested due to anti-inflammatory and antioxidant responses of HP during the progression of cardiovascular disease. Treatments of atorvastatin and Ficus extracts maintained the same pattern as in $\mathrm{HC}$ suggesting the corrective effort of the treatments posthypercholesterolemic induction.

Significant differences were also observed in proteins relevant to inflammation and immune system. Both complement components (C3 and $\mathrm{C} 1 \mathrm{~s})$ were markedly increased in $\mathrm{HC}$ rats due to the progression of complement activation in atherosclerotic lesions beyond the foam cell stage. C3 isolated from hypercholesterolemic subjects were apparently enriched in HDL and related to innate immunity as well as HDL's cardioprotective effect (Vaisar et al. 2007). Hence, many studies concluded the elevated plasma $\mathrm{C} 3$ level in inflammatory condition is associated with myocardial infarction (Muscari et al. 2001), hypertension (Engström et al. 2007) and atherosclerosis (Alwaili et al. 2012). However, no apparent difference was observed in $\mathrm{HC}$ rats treated with lipid lowering drug (Atorvastatin). This may due to inadequate treatment period (Muscari et al. 2001) to reduce the elevated C3 levels. In contrary, the $\mathrm{C} 3$ level in HC-E250 treated HC decreased in abundance. This indicates that $F$. deltoidea extract may be involved in non-lipid lowering effects and postulated anti- inflammatory mechanisms when higher dosage of $F$. deltoidea extract consumed.

TTR also known as prealbumin is a tetrameric structured protein that derives mainly from the liver and the choroid plexus of the brain. TTR functions to transport protein for thyroxine (T4), triiodothyronine (T3) and retinol (Vitamin A) (van Bennekum et al. 2001). TTR is an important protein in cholesterol metabolism (Liz et al. 2007) and currently a new found inflammation marker for CVD (von Zychlinski \& Kleffmann 2015). Treatments with atorvastatin and low concentration of $F$. deltoidea (HC-E50) significantly increased TTR abundantly when compared to HC rats. Intriguingly, TTR is regulated by HDL in correspondence of lipid-free Apo A1, and the stability of the HDL fragments is not affected by the existence or absence of TTR (Sousa et al. 2000).

PLG is another cardiovascular related protein in this study, which play crucial role in arterial thrombosis (Deitcher \& Jaff 2002). PLG and the derived serine protease, plasmin, together with the Plasminogen Activator Inhibitors (PAI) had postulated to influence cardiovascular inflammatory responses mainly in clot dissolving properties. This effect also occurred in $F$. deltoidea extracts treatment in which PLG markedly downregulated on $\mathrm{HC}$ rats. Hence, there are plausible thrombolytic effects of $F$. deltoidea extract in reducing the risk of thrombosis in cardiovascular event.

The molecular and physiological functions of PROM1 and ENPP3 remain unclear. In an earlier work by Yang et al. (2007) reported that the hyperglycemic event in their animal study induced the expression of PROM1 in rat's skeletal muscle by raising glyceraldehyde 3- phosphate dehydrogenase (GADPH) enzyme which further attached to the LDLs in the blood, forming the atheromatous or sticky plaques. In our present study, PROM1 in HC group was slightly increased in abundance. Upon treatments with atorvastatin and $F$. deltoidea extracts, it could be observed that PROM1 was reduced. ENPP3 is localised in apical plasma membrane and also in vascular smooth muscle. This ENPP hydrolysed the phosphodiester bonds in phospholipids compound. However, as summarised from the Ingenuity Pathway Analysis (IPA), the biological functions of ENPP3 mainly occur in inflammations.

Subjecting the putative proteins to the IPA analysis; Apo A1, Apo E, RBP4, HP, ENPP3, C3, C1s, PROM1, TTR and PLG were predicted to contribute to the top biological function network on 'Lipid Metabolism, Molecular Transport, Small Molecule Biochemistry' with the most significant canonical pathway analysis in acute phase response signaling. This further support the speculation on acute phase protein molecular involvement in anti-inflammatory effects of $F$. deltoidea. However, the network enormously identified Apo A1 and Apo E involvements in lipid synthesis and clearance in cell. These two proteins also demonstrated direct interaction with HDL in the network. 


\section{CONCLUSION}

In conclusion, this study had demonstrated the suppression of hypercholesterolemia following $F$. deltoidea treatment with differential expression of serum proteins involved in lipid metabolism and transport, inflammation and immune response, antioxidant protein, acute phase protein, cholesterol homeostasis, fatty acid catabolism, and cholesterol binding. These hypercholesterolemic related proteins (Apo A1, Apo E, RBP4, HP, PDE1, C3, C1s, PROM1, TTR, and PLG) are the key proteins responsible for the suppression of hypercholesterolemia following treatment with $F$. deltoidea. The variations of these proteins may provide valuable new molecular insights into the mechanism of cholesterol lowering effect of $F$. deltoidea. Thus, further development of this study will enable the finding of alternative treatments as well as preventions for CVD.

\section{ACKNOWLEDGEMENTS}

This research was financially supported by University of Malaya High Impact Research (HIR) (UM.0000105/HIR. C3) and University of Malaya Postgraduate Research Grant (PPP) (PG219-2014B). Proteomics analysis was conducted with access to the Medical Biotechnology Laboratory, Faculty of Medicine, University of Malaya.

\section{REFERENCES}

Abdullah, Z., Hussain, K., Ismail, Z. \& Ali, R.M. 2009. Antiinflammatory activity of standardised extracts of leaves of three varieties of Ficus deltoidea. International Journal of Pharmaceutical and Clinical Research 1(3): 100-105.

Alwaili, K., Bailey, D., Awan, Z., Bailey, S.D., Ruel, I., Hafiane, A., Krimbou, L., Laboissiere, S. \& Genest, J. 2012. The HDL proteome in acute coronary syndromes shifts to an inflammatory profile. Biochimica et Biophysica Acta (BBA)-Molecular and Cell Biology of Lipids 1821(3): 405415.

Alwi, N.A.N.M., Zakaria, Z., Karim, A.A.H., Nordin, N.A.M.M. \& Ugusman, A. 2018. Antihypertensive effect of Piper sarmentosum in L-NAME-induced hypertensive rats. Sains Malaysiana 47(10): 2421-2428.

Carbone, F. \& Montecucco, F. 2015. Inflammation in arterial diseases. IUBMB Life 67(1): 18-28.

Carbone, F., Mach, F. \& Montecucco, F. 2015. The role of adipocytokines in atherogenesis and atheroprogression. Current Drug Targets 16(4): 295-320.

Deitcher, S.R. \& Jaff, M.R. 2002. Pharmacologic and clinical characteristics of thrombolytic agents. Reviews in Cardiovascular Medicine 3(2): 25-33.

Engström, G., Hedblad, B., Berglund, G., Janzon, L. \& Lindgärde, F. 2007. Plasma levels of complement $\mathrm{C} 3$ is associated with development of hypertension: A longitudinal cohort study. Journal of Human Hypertension 21: 276-282.

Graham, T.E., Wason, C.J., Blüher, M. \& Kahn, B.B. 2007. Shortcomings in methodology complicate measurements of serum retinol binding protein (RBP4) in insulin-resistant human subjects. Diabetologia 50(4): 814-823.
Hadijah, H., Normah, A., Ahmad Tarmizi, S., Abidin, H. \& Musa, Y. 2004. Safety evaluation of mas cotek tea: Effect on organ weight and blood biochemistry. Proceedings of the Seminar on Medicinal and Aromatic Plants: Current Trends and Perspective. pp. 20-21.

Hakiman, M. \& Maziah, M. 2009. Non enzymatic and enzymatic antioxidant activities in aqueous extract of different Ficus deltoidea accessions. Journal of Medicinal Plants Research 3(3): 120-131.

Hansson, G.K. \& Libby, P. 2006. The immune response in atherosclerosis: A double-edged sword. Nature Reviews Immunology 6: 508-519.

Harrison, D., Griendling, K.K., Landmesser, U., Hornig, B. \& Drexler, H. 2003. Role of oxidative stress in atherosclerosis The American Journal of Cardiology 91(3): 7-11.

Hasham, R., Choi, H.K., Sarmidi, M.R. \& Park, C.S. 2013. Protective effects of a Ficus deltoidea (Mas cotek) extract against UVB-induced photoageing in skin cells. Biotechnology and Bioprocess Engineering 18(1): 185-193.

Heinecke, J.W. 2009. The HDL proteome: A marker and perhaps mediator of coronary artery disease. Journal of Lipid Research 50: 167-171.

Ibrahim, F.W., Derased, N.I., Zainudin, U.R.A. \& Rajab, N.F. 2018. Mechanism identification of Ficus deltoidea aqueous extract in rat uterine contractions. Jurnal Sains Kesihatan Malaysia Isu Khas 16: 75-81.

Kalman, D.S., Schwartz, H.I., Feldman, S. \& Krieger, D.R. 2013. Efficacy and safety of Elaeis guineensis and Ficus deltoidea leaf extracts in adults with pre-diabetes. Nutrition Journal 12(1): 1-7.

Khanna, A.K., Chander, R. \& Kapoor, N.K. 1996. Terminalia arjuna: An ayurvedic cardiotonic, regulates lipid metabolism in hyperlipaemic rats. Phytotherapy Research 10(8): 663-665.

Kim, H.J., Yoo, H.S., Kim, P.K., Kim, M.R., Lee, H.W. \& Kim, C.W. 2011. Comparative analysis of serum proteomes of patients with cardiovascular disease. Clinical Biochemistry 44(2): 178-184.

Laufs, U., Karmann, B. \& Pittrow, D. 2016. Atorvastatin treatment and LDL cholesterol target attainment in patients at very high cardiovascular risk. Clinical Research in Cardiology 105(9): 783-790.

Leopold, J.A. \& Loscalzo, J. 2009. Oxidative risk for atherothrombotic cardiovascular disease. Free Radical Biology and Medicine 47(12): 1673-1706.

Liz, M.A., Gomes, C.M., Saraiva, M.J. \& Sousa, M.M. 2007. ApoA-I cleaved by transthyretin has reduced ability to promote cholesterol efflux and increased amyloidogenicity. Journal of Lipid Research 48(11): 2385- 2395.

Mat, N., Rosni, N.A., Ab Rashid, N.Z., Haron, N., Nor, Z.M., Nudin, N.F.H., Yunus, A.G. \& Ali, A.M. 2012. Leaf morphological variations and heterophylly in Ficus deltoidea jack (Moraceae). Sains Malaysiana 41(5): 527-538

Ministry of Health Malaysia. 2017. Clinical Practice Guidelines. Management of Dyslipidaemia 2017. 5th edition. Putrajaya: Ministry of Health Malaysia.

Misbah, H., Aziz, A.A. \& Aminudin, N. 2013. Antidiabetic and antioxidant properties of Ficus deltoidea fruit extracts and fractions. BMC Complementary and Alternative Medicine 13(1): 118.

Moore, K.J. \& Tabas, I. 2011. Macrophages in the pathogenesis of atherosclerosis. Cell 145(3): 341-355. 
Muscari, A., Bastagli, L., Poggiopollini, G., Tomassetti, V., Massarelli, G., Boni, P. \& Puddu, P. 2001. Short term effect of atorvastatin and vitamin $\mathrm{E}$ on serum levels of $\mathrm{C} 3$, a sensitive marker of the risk of myocardial infarction in men. Cardiovascular Drugs and Therapy 15(5): 453-458.

Oh, M.J., Hamid, M.A., Ngadiran, S., Seo, Y.K., Sarmidi, M.R. \& Park, C.S. 2011. Ficus deltoidea (Mas cotek) extract exerted anti-melanogenic activity by preventing tyrosinase activity in vitro and by suppressing tyrosinase gene expression in $\mathrm{B} 16 \mathrm{~F} 1$ melanoma cells. Archives of Dermatological Research 303(3): 161-170.

Parekh, R. 1999. Proteomics and molecular medicine. Nature Biotechnology 17: 19-20.

Razali, N., Dewa, A., Asmawi, M.Z., Ismail, Z., Manshor, N.M. \& Hassan, Z. 2013. Vascular reactivity on aortic rings of spontaneously hypertensive rats treated with methanolic and water extracts of Ficus deltoidea. Journal of Experimental \& Integrative Medicine 3(2): 93-102.

Sousa, M.M., Berglund, L. \& Saraiva, M.J. 2000. Transthyretin in high density lipoproteins: Association with apolipoprotein A1. Journal of Lipid Research 41(1): 58-65.

Sulaiman, M.R., Hussain, M.K., Zakaria, Z.A., Somchit, M.N., Moin, S., Mohamad, A.S. \& Israf, D.A. 2008. Evaluation of the antinociceptive activity of Ficus deltoidea aqueous extract. Fitoterapia 79(7): 557-561.

Tachjian, A., Maria, V. \& Jahangir, A. 2010. Use of herbal products and potential interactions in patients with cardiovascular diseases. Journal of the American College of Cardiology 55(6): 515-525.

Thong-asa, W., Prasertsuksri, P., Sakamula, R. \& Nimnuan, T. 2019. Effect of Tiliacora triandra leaf extract on glycemic control in mice with high sugar intake. Sains Malaysiana 48(9): 1989-1995.

Vaisar, T., Pennathur, S., Green, P.S., Gharib, S.A., Hoofnagle, A.N., Cheung, M.C., Byun, J., Vuletic, S., Kassim, S., Singh, P. \& Chea, H. 2007. Shotgun proteomics implicates protease inhibition and complement activation in the anti-inflammatory properties of HDL. Journal of Clinical Investigation 117(3): 746-756.

van Bennekum, A.M., Wei, S., Gamble, M.V., Vogel, S., Piantedosi, R., Gottesman, M., Episkopou, V. \& Blaner, W.S. 2001. Biochemical basis for depressed serum retinol levels in transthyretin-deficient mice. Journal of Biological Chemistry 276(2): 1107-1113. von Zychlinski, A. \& Kleffmann, T. 2015. Dissecting the proteome of lipoproteins: New biomarkers for cardiovascular diseases? Translational Proteomics 7: 30-39.

Wong, N.D. 2014. Epidemiological studies of CHD and the evolution of preventive cardiology. Nature Reviews Cardiology 11: 276-289.

Yan, J.X., Wait, R., Berkelman, T., Harry, R.A., Westbrook, J.A., Wheeler, C.H. \& Dunn, M.J. 2000. A modified silver staining protocol for visualization of proteins compatible with matrix-assisted laser desorption/ionization and electrospray ionization-mass spectrometry. ELECTROPHORESIS: An International Journal 21(17): 3666-3672.

Yang, C., Yang, Y., Gupta, N., Liu, X., He, A., Liu, L., Zuo, J., Chang, Y. \& Fang, F. 2007. Pentaspan membrane glycoprotein, prominin-1, is involved in glucose metabolism and cytoskeleton alteration. Biochemistry (Moscow) 72(8): 854-862.

Chuo Peck Ham, Fatima Uzar, Noorlidah Abdullah \& Norhaniza Aminudin*

Institute of Biological Sciences

Faculty of Science

University of Malaya

50603 Kuala Lumpur, Federal Territory

Malaysia

Puteri Shafinaz Abdul-Rahman

Department of Molecular Medicine

Faculty of Medicine

University of Malaya

50603 Kuala Lumpur, Federal Territory

Malaysia

Puteri Shafinaz Abdul-Rahman \& Norhaniza Aminudin* University of Malaya Centre for Proteomics Research (UMCPR) University of Malaya

50603 Kuala Lumpur, Federal Territory

Malaysia

*Corresponding author; email: hanizaaminudin@um.edu.my

Received: 2 September 2019

Accepted: 28 January 2020 